\title{
Hot air drying characteristics and nutrients of apricot armeniaca vulgaris Iam pretreated with Radio Frequency(RF)
}

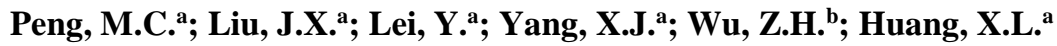 \\ ${ }^{a}$ College of Food Engineering and Nutritional Science, Shaanxi Normal University, Shaanxi xi'an, \\ 710119, China \\ b College of Mechanical Engineering, Tianjin University of Science and Technology, 1038 Dagu South \\ Rd., Hexi, Tianjin, 300222, China
}

*E-mail of the corresponding author: cauxlhuang@hotmail.com

\begin{abstract}
Apricot pretreated with $R F$ and then dried with convective hot air at $65^{\circ} \mathrm{C}$, $3.0 \mathrm{~m} / \mathrm{s}$ in this research. RF pretreatment time of 20, 30, 40 and 50min were chosen. Results showed that, there is only falling rate period during apricot hot air drying, and the drying rate of apricot is improved significantly; Herdenson and Pabis model is suitable for apricot hot air drying; retentions of flavonoids, polyphenols and Vc in dried apricot were higher than those of fresh apricot; when RF treating time was chosen 30mins, nutrients retentions of $\mathrm{Vc}$, flavonoid and polyphenols were $0.9543 \mathrm{mg} / 100 \mathrm{~g}, 5.4089 \mathrm{mg} / 100 \mathrm{~g}$ and $7.3382 \mathrm{mg} / 100 \mathrm{~g}$, separately.
\end{abstract}

Keywords: apricot fruit, hot air drying, drying rate, nutrients, radio frequency 


\section{Introduction}

Apricot originated in China. It has a wide distribution, high yield, good quality and unique flavor. However, fresh apricot fruit with high moisture content above $80 \%$ is easy to corrupt at normal temperature even cold storage ${ }^{[1]}$. Drying is an effective method to extent selft life of apricot. Half dried preserved apricot fruits are popular to Chinese. So, there are several literals about drying of apricot fruits. Wang studied on thin layer drying of apricot at low temperature and different air velocities, and temperature is the main factor affecting drying rate ${ }^{[2]}$. Natural air drying of apricot is time consuming and induces serious browning which affects the quality of dried apricot ${ }^{[3]}$. In order to prevent browning, blanching before drying or sulphur treated during drying is usual applied. And these treatments either high temperature, nutrients $\operatorname{loss}^{[4]}$ or unsafe for health. New type of heating method, RF receives more and more attentions in recent years for lots of advantages such as selective heating, selfbalancing effect of moisture content, large energy penetration depth and fast heating rate ${ }^{[5]}$, etc. There are several literatures on RF used in drying of agricultural products, deinsectization, sterilization ${ }^{[6,8]}$. Zhang and others ${ }^{[9]}$ investigated RF conbimed with hot air drying red jujube, drying time was shortened by $2 / 3$. In roder to reduce drying time and improve the quality of dried apricot, RF technique was applied in this paper, and then convective hot air drying at $65^{\circ} \mathrm{C}$ was conducted.

\section{Materials and Methods}

\subsection{Samples preparation}

Apricot armeniaca vulgaris lam was provided by the institute of plum and apricot, Xi'an, in May to July,2017. Fresh apricots were stored at $3-4^{\circ} \mathrm{Cand}$ must be used within one week. The initial moisture of fresh apricot ranged from $85 \%$ to $86 \%$ wet basis which was determination by oven drying at $103^{\circ} \mathrm{C}$. Samples were cut in half and the cores were removed, and then immersed in $2 \%$ sodium bisulfite solution for 1 hour to restrain browning.

\subsection{RF pretreatment of apricot}

Apricot fruits were moved into the RF equipment and the plate distance was set $60.0 \mathrm{~mm}$. The power of the radio frequency equipment is $6.0 \mathrm{KW}$ and the frequency is $27.1 \mathrm{~Hz}$. RF treated time was chosen for 20, 30, 40, and 50min.

\subsection{Hot air drying experiment of apricot}

After RF pretreatment, apricot was dried with convective hot air at $65^{\circ} \mathrm{C}$ and air velocity of $3.0 \mathrm{~m} / \mathrm{s}$. During the drying period water content of apricot was declined from nearly $84 \%$ to about $20 \%$. In order to analyze the drying characteristics of apricot pretreated with RF, the weights of samples were obtained by electronic balance with an accuracy of $0.001 \mathrm{~g}$ every 60 minutes. 


\subsection{Nutrients assay}

The flavonoid content of apricot fruit pulp was analyzed according the method described by Liang ${ }^{[10]}$ with slight amendent. $1.0 \mathrm{ml}$ of filtrate was placed in a $25 \mathrm{ml}$ volumetric flask, and then $6 \mathrm{ml}$ of distilled water and $1.0 \mathrm{ml}$ of sodium nitrite (1:20) were added in turn and shaked well. After 6 minutes, $1.0 \mathrm{ml}$ of aluminium nitrate (1:10) was added and shaked well, and 6minutes later, $10.0 \mathrm{ml}$ of sodium hydroxide (1:10) was added and shake well. After 15 minutes' standing, the final volume was made up to $25 \mathrm{ml}$ with distilled water and shade well. And the sample was placed in colorimetric tube and the absorbance was measured at $510 \mathrm{~nm}$.

Phenolic content in apricot was determined by the Folin-Ciocalteau method ${ }^{[11]}$. 2,6dichlorophenol indophenol method ${ }^{[12]}$ was applied to assay vitamin $\mathrm{C}$ content of apricot in this study.

All measurements were conducted in triplicate.

\section{Results and discussion}

\subsection{Drying characteristics of apricot preteated with RF}

After RF pretreatment, the apricot fruit was dried with hot air at $65^{\circ} \mathrm{C}$ and on the velocity of $3.0 \mathrm{~m} / \mathrm{s}$. There is only falling rate period during apriod hot air drying, shown in Figure 1 . The drying rate of apricot pretreated with RF was obviously higher than that of control sample, because RF treatment can improve the permeation of apricot, that would induce moisture migrate quickly. In the range of 20-50minutes RF treated, the drying rate of apricot fruit increased with the increase of RF treated time. And the drying rate of apricot fruit with 50 minutes' RF pretreatment was the highest, while that of apricot with 20minutes' RF treatment was the lowest. May be the longer RF treated time, the permeation of apricot tissue was better, which makes it easier for moisture migrate in subsequent drying process.

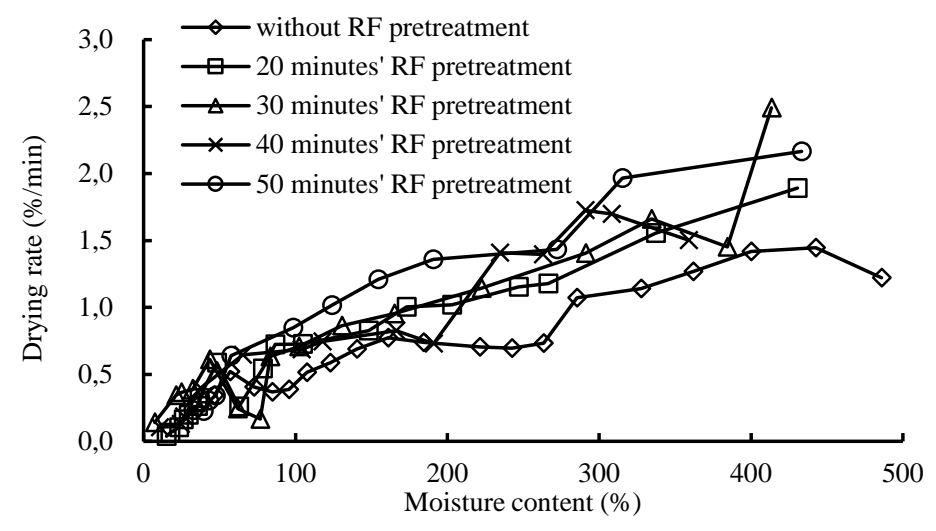

Fig.1 Drying rate curves of apricot during hot air drying after different RF pretreatments

In this paper, moisture ratio was applied to analyze the drying characteristics, shown in equation $(1)^{[13,14]}$. 
Hot air drying characteristics and nutrients of apricot armeniaca vulgaris lam pretreated with Radio Frequency $(R F)$

$$
M R=\frac{M_{t}-M_{e}}{M_{0}-M_{e}}
$$

Where, $M_{0}, M_{e}$ and $M_{t}$ stand for initial moisture content, equation moisture content and moisture content at any time, sepretively, dry basis, \%. As $M_{e}$ was difficult to determinte at laboratory, it was neglected in this paper. So, equation(1) was simplified as equation(2).

$$
M R=\frac{M_{t}}{M_{0}}
$$

From the curves of moisture content of apricot preteated with RF during hot air drying, as showed in figure 2, moisture content of apricot pretreated with RF delined more fast than that of control samples. And the drying time was shorten by $10 \%$ to $34 \%$. That means RF ptretreatment could save drying time and energy.

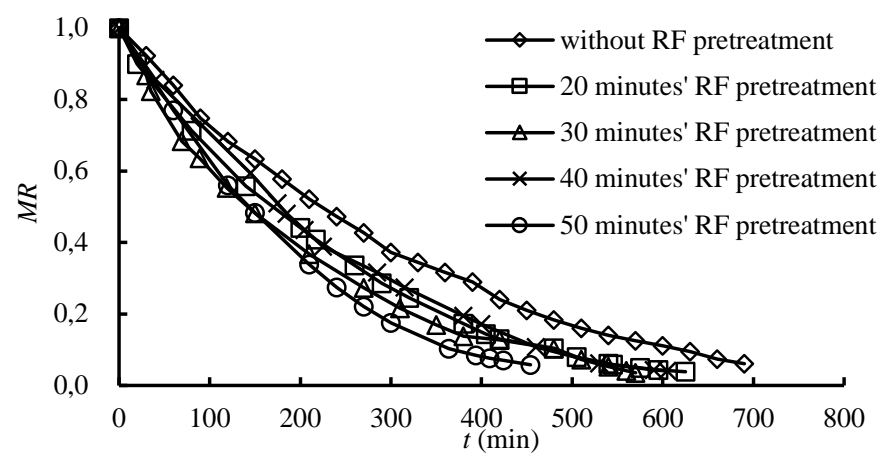

Fig.2 Curves of moisture ratio of apricot changing with drying time during hot air drying

\subsection{Hot air drying model of apricot pretreated with RF}

There are many mathematics models to describe drying characteristics of fruits and vegetables $^{[15-19]}$. Through analyse of experiment data, it was found that, Herdenson and Pabis model, Page model and Lemus model, showed in table 1, were better consistent with experiment data. $R^{2}, \chi^{2}$, and RMSE of evey model, as equations from (3) to (5), were used as indications to evaluate drying model. Henderson and Pabis model has the highest R2 ranging from 0.9715 to 0.9955 , and has lower $\chi^{2}$ and RMSE. So Henderson and Pabis model was better fit for experiment data.

$$
\begin{gathered}
R^{2}=1-\frac{\sum_{i=1}^{N}\left(M R_{\exp , i}-M R_{p r e, i}\right)^{2}}{\sum_{i=1}^{N}\left(\overline{M R} R_{\exp }-M R_{p r e, i}\right)^{2}} \\
\chi^{2}=\frac{\sum_{i=1}^{N}\left(M R_{\exp , i}-M R_{p r e, i}\right)^{2}}{N-n} \\
R M S E=\sqrt{\frac{\sum_{i=1}^{N}\left(M R_{\text {exp }, i}-M R_{p r e, i}\right)^{2}}{N}}
\end{gathered}
$$


Peng, M.C.; Liu, J.X.; Lei, Y.; Yang, X.J.; Wu, Z.H.; Huang, X.L.

Table $1 R^{2}, R M S E, \chi^{2}$ of hot air drying models for apricot pretreated with $R F$

\begin{tabular}{|c|c|c|c|c|c|c|c|}
\hline \multirow{2}{*}{\begin{tabular}{l}
\multicolumn{1}{c}{$\mathrm{RF}$} \\
treatment \\
time/min
\end{tabular}} & \multirow[t]{2}{*}{$\begin{array}{l}\text { Model } \\
\text { name }\end{array}$} & \multirow{2}{*}{$\begin{array}{l}\text { Model } \\
\text { equation }\end{array}$} & \multicolumn{2}{|c|}{ Model parameters } & \multirow[t]{2}{*}{$R^{2}$} & \multirow[t]{2}{*}{ RMSE } & \multirow[t]{2}{*}{$\chi^{2}$} \\
\hline & & & $a$ & $k$ & & & \\
\hline 20 & \multirow{4}{*}{$\begin{array}{c}\text { Henderson } \\
\text { and Pabis }\end{array}$} & \multirow{4}{*}{$M R=a \exp (-k t)$} & 1.0432 & $-8.7 \times 10^{-5}$ & 0.9900 & 0.0386 & 0.0016 \\
\hline 30 & & & 0.9867 & $-9.8 \times 10^{-5}$ & 0.9715 & 0.0525 & 0.0031 \\
\hline 40 & & & 1.1035 & $-9.5 \times 10^{-5}$ & 0.9879 & 0.0703 & 0.0057 \\
\hline \multirow[t]{2}{*}{50} & & & 1.0839 & $-10.8 \times 10^{-5}$ & 0.9927 & 0.0505 & 0.0030 \\
\hline & \multirow{5}{*}{ Page } & \multirow{5}{*}{$M R=\exp \left(-k t^{n}\right)$} & $k$ & $n$ & & & \\
\hline 20 & & & $6.6177 \times 10^{-5}$ & 1.0237 & 0.9895 & 0.0279 & 0.0009 \\
\hline 30 & & & $2.4486 \times 10^{-3}$ & 0.6724 & 0.9255 & 0.0593 & 0.0039 \\
\hline 40 & & & $3.9567 \times 10^{-5}$ & 1.0796 & 0.9929 & 0.0394 & 0.0018 \\
\hline \multirow[t]{2}{*}{50} & & & $0.5086 \times 10^{-5}$ & 1.3344 & 0.9871 & 0.0607 & 0.0043 \\
\hline & \multirow{5}{*}{ Lemus } & \multirow{5}{*}{$M R=a_{1}+a_{2} t^{1 / 2}$} & $a_{1}$ & $a_{2}$ & & & \\
\hline 20 & & & 0.9070 & $-4.6 \times 10^{-3}$ & 0.9644 & 0.0460 & 0.0027 \\
\hline 30 & & & 0.8862 & $-4.8 \times 10^{-3}$ & 0.9872 & 0.0403 & 0.0018 \\
\hline 40 & & & 0.8856 & $-4.6 \times 10^{-3}$ & 0.9751 & 0.0460 & 0.0024 \\
\hline 50 & & & 0.9826 & $-5.8 \times 10^{-3}$ & 0.9820 & 0.0349 & 0.0014 \\
\hline
\end{tabular}

\subsection{Analyze of nutrients in dried apricot}

\subsubsection{Flavonoids in apricot pretreated with $R F$}

At the bigining of drying, total flavonoid content was the one of fresh apricot. From figure 3(a), it was known that, as moisture descrease, total flavonoid contents of apricots pretreated with RF were increased firstly and then declined, but higher than that of fresh apricot. The reason might be RF treatment induce fruits tissue collapsed that would favorable for testing nutrients. It also can be found that, when RF treatment time was chosen $40 \mathrm{~min}$, flavonoid contents of apricot maitaned highest level during the hole drying process, those of apricots pretreated with $30 \mathrm{~min}$ and $50 \mathrm{~min}$ were flowed by, and the last was 20minutes' RF pretreatment. The main reason might be tissue permeation of apricot would improve as the RF treteated time but there exists a limit level for permeation; and prolong RF pretreated time, nutrients were degraded or decomposed.

When dying was finished, flavonoid content in dried apricots also maintaned higher than of fresh apricot $(0.9075 \mathrm{mg} / 100 \mathrm{~g})$. The main reason would be that RF destroyed internal structures of apricots, and flavones in tissue were easy to dissolve out.

\subsubsection{Polyphenol content in apricot pretreated with RF}

It was obvious showed that, after 30 and 40 minutes' RF pretreatment, polyphenol contents of apricot during hot air drying maitaned the highest level, and those of samples with 20 munites' RF pretreatment were follow by, and those of samples with 50 munites' RF 
pretreatment were the lowest, showed in figure 3(b). The reason for this phenonena as the above. But, longer time RF pretreatment may destroy polyphenol tissue and induced oxidation. The result from this study were consistent with that from Zhao et a ${ }^{[20]}$. During the hot air drying process, polyphenol contents maintain stable level and did not decline with the descrease of moisture content of apricot.

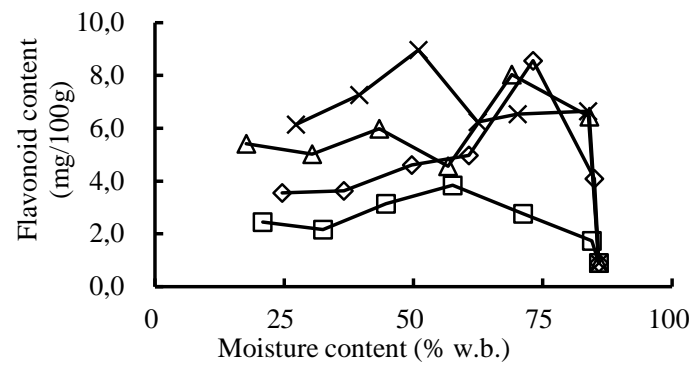

(a) Flavonoid contents

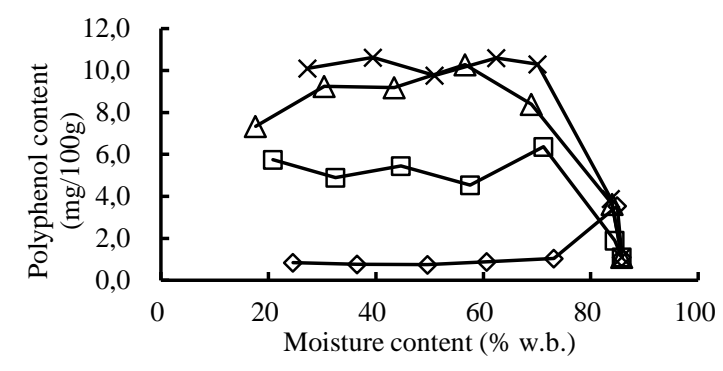

(b) Polyphenol Content

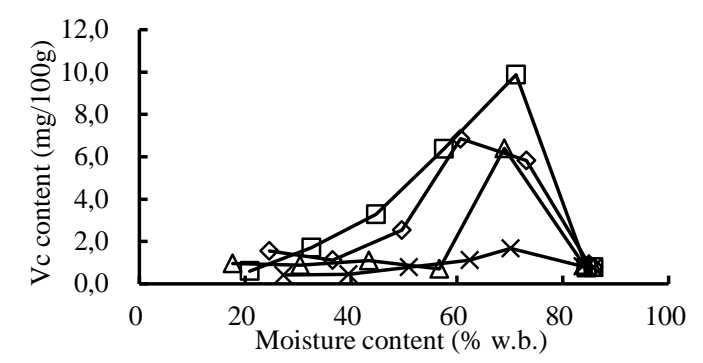

(c) Vc content

$\square 20$ minutes' RF pretreatment $\quad \triangle 30$ minutes' RF pretreatment

* 40 minutes' RF pretreatment $\multimap 50$ minutes' RF pretreatment

Fig.3 Nutrients of apricot pretreated with RF changing with moisture content in hot air drying

\subsubsection{Vitamin $C$ in apricot pretreated with $R F$}

As soon as RF pretreated, Vc content in apricot were sharply increased compared to that of fresh sample, showed in figure 3(c). However, Vc is heat sensitive material, as drying 
processing, it was decreased as the descrease of moisture content of apricot. And the 40 minutes' RF pretreatment could induce the better permeation of apricot tissue analzed above, so more Vc in apricot was exposed on the surface of wet matial, that meant more Vc would degrade wthen exposed in high temperature condiction. When hot air drying was finished, Vc contents of dried apricot with different RF pretreated were slightly higher than that of fresh fruit $(0.7817 \mathrm{mg} / 100 \mathrm{~g})$.

From the above nutrients analyze, when RF treating time was chosen 30 minutes, nutrients retentions of flavonoid, polyphenols and Vc were $5.4089 \mathrm{mg} / 100 \mathrm{~g}, 7.3382 \mathrm{mg} / 100 \mathrm{~g}$, and $0.9543 \mathrm{mg} / 100 \mathrm{~g}$, separately.

\section{Conclusions}

RF treatment could improve the hot air drying rate of apricot, and saving time and energy. After RF pretreatment, nutrients of flavonoids and polyphenol in apricot were improved and maintain higher levels during hot air drying, although vitamin $\mathrm{C}$ was higher just after RF pretreatment, it was degraded during hot air drying. Overall, RF would be a new pretreatment technique for fruit and vegetables drying.

\section{Acknowledgements}

The work was financially supported by the Fundamental Research Funds for the Central Universities of China (NO. GK201503072 and GK201601007).

\section{References}

[1] Oluranti, E.; Campbell, I.A.; Merwin.; Olga, I. Characterization and the effect of maturity at harvest on the phenolic and carotenoid content of northeast USA apricot(Prunus armeniaca) varieties. Journal of Agricultural and Food Chemistry 2013, 61, 12700-12710.

[2] Wang, N.; Liu, W.X.; Li, F.C.; Du. Z.L. Thin layer drying model of apricot at low temperature. Transactions of the Chinese Society for Agricultural Machinery 2011, 42(1), 140-144.

[3] Zhang, Z.N.; Wang, J.; Zhang, X.Y.; Shi, Q.L. Effects of radio frequency assisted blanching on polyphenol oxidase, weight loss, texture, color and microstructure of potato. Food Chemistry 2018, 248,173-182.

[4] Cabras, P.; Angioni, A.; Vincenzo, L. Pesticide residues on field-sprayed apricots and in apricot drying processes. Journal of Agricultural and Food Chemistry 1998, 46, 23062308.

[5] Liu, Y.H.; Wang, S.J.; Mao, Z.H.; Tang, J.M.; Tiwari, G. Heating patterns of white bread loaf in combined radio frequency and hot air treatment. Journal of Food Engineering 2013, 116, 472-477.

[6] Zhang, S.; Zhou, L.Y.; Ling, B.; Wang, S.J. Dielectric properties of peanut kernels, ssociated with microwave and radio frequency drying. Biosystems engineering 2016, $145,108-117$.

[7] Tiwari, G.; Wang, S.; Tang, J.; Birla, S.L. Analysis of radio frequency (RF) power 
distribution in dry food materials. Journal of Food Engineering 2011,104, 548-556.

[8] Hansen, J.D.; Drake, S.R.; Heidt, M.L.; Watkins, M.A.; Tang, J.; Wang, S. Radio frequency-hot water dips for postharvest codling moth control in apples. Journal of Food Processing and Preservation 2006, 30(6), 631-642.

[9] Wang, J.; Olsen, R.G.; Tang, J.; Tang, z. Influence of mashed potato dielectric properties and circulating water electric conductivity on radio frequency heating at $27 \mathrm{MHz}$. Journal of Microwave Power \& Electromagnetic Energy 2008, 42(2), 31-46.

[10] Liang, X.F. et.al. Extraction technology of flavonoids from ginkgo biloba L. Shells Medicinal Plant 2012, (10), 64-69.

[11] Oluranti, E.; Campbell, I.A.; Merwin.; Olga, I. Padilla-Zakour characterization and the effect of maturity at harvest on the phenolic and carotenoid content of northeast USA apricot (Prunus armeniaca) varieties. Journal of Agricultural and Food Chemistry 2013, 61, 12700-12710.

[12] O’Callaghan, J.R.; Menzies, D.J.; Bailey, P.H. Digital simulation of agricultural dryer performance. Journal of Agricultural Engineering Research 1971, 16(3), 223-244.

[13] Xiao, H.W.; Pang, C.L.; Wang, L.H.; Bai, J.W.; Yang, W.X.; Gao, Z.J. Drying kinetics and quality of Mounkka seedless grapes dried in an air-impingement jet dryer. Biosystems Engineering 2010, 105, 233-240.

[14] Danae, D.K.; Tzia, V.; Gekas. A knowledge base for the apparent mass diffusion coefficient ( $\left.D_{\mathrm{EFF}}\right)$ of foods. International Journal of Food Properties 2000, 3(1), 1-14.

[15] Arslan, D.; Özcan, M. M. Drying of tomato slices: changes in drying kinetics, mineral contents, antioxidant activity and color parameters Secado de rodajas de tomate: cambios en cinéticos del secado, contenido en minerales, actividad antioxidante y parámetros de color CyTA. Journal of Food 2011, 9(3), 229-236.

[16] Silva, W.P.; Silva, C.M.D.P.S.; Gama, F.J.A.; Gomes, J.P. Mathematical models to describe thin-layer drying and to determine drying rate of whole bananas. Journal of the Saudi Society of Agricultural Sciences 2014, 13, 67-74.

[17] Baini, R.; Langrish, T.A.G. Choosing an appropriate drying model for intermittent and continuous drying of bananas. Journal of Food Engineering 2007, 79; 330-343.

[18] Yu, H.M.; Zuo, C.C.; Xie, Q.J.; Makinde, O.D. Drying characteristics and model of chinese hawthorn using microwave coupled with hot air. Mathematical Problems in Engineering 2015, 1-15.

[19] Bi, J.F.; Yang, A.J.; Liu, X.; Wu, X.Y.; Chen, Q.Q.; Wang, Q.; Lv, J.; Wang, X. Effects of pretreatments on explosion puffing drying kinetics of apple. LWT-Food Science and Technology 2015, 60, 1136-1142.

[20] Zhao, E.L.; Wang, M.H.; Zhan, J.L.; Yang, J.Study on microwave-assisted extraction of polyphenol from corn bract based on response surface methodology and its antioxidant activity. Molecular Plant Breeding 2018, online first (in Chinese with English abstract) 